\title{
Three horizons: a pathways practice for transformation
}

\author{
Bill Sharpe $^{1}, \underline{\text { Anthony Hodgson }}^{1,2}$, Graham Leicester $^{1}$, Andrew Lyon $^{1}$ and Ioan Fazep $^{2}$
}

\begin{abstract}
Global environmental change requires responses that involve marked or qualitative changes in individuals, institutions, societies, and cultures. Yet, while there has been considerable effort to develop theory about such processes, there has been limited research on practices for facilitating transformative change. We present a novel pathways approach called Three Horizons that helps participants work with complex and intractable problems and uncertain futures. The approach is important for helping groups work with uncertainty while also generating agency in ways not always addressed by existing futures approaches. We explain how the approach uses a simple framework for structured and guided dialogue around different patterns of change by using examples. We then discuss some of the key characteristics of the practice that facilitators and participants have found to be useful. This includes (1) providing a simple structure for working with complexity, (2) helping develop future consciousness (an awareness of the future potential in the present moment), (3) helping distinguish between incremental and transformative change, (4) making explicit the processes of power and patterns of renewal, (5) enabling the exploration of how to manage transitions, and (6) providing a framework for dialogue among actors with different mindsets. The complementarity of Three Horizons to other approaches (e.g., scenario planning, dilemma thinking) is then discussed. Overall, we highlight that there is a need for much greater attention to researching practices of transformation in ways that bridge different kinds of knowledge, including episteme and phronesis. Achieving this will itself require changes to contemporary systems of knowledge production. The practice of Three Horizons could be a useful way to explore how such transformations in knowledge production and use could be achieved.
\end{abstract}

Key Words: adaptation pathways; climate change; scenarios; transformation; transition

\section{INTRODUCTION}

Climate and other environmental change is a serious threat to the security and well-being of the expected 9-10 billion population of the planet (Rockstrom et al. 2009, Nicholls et al. 2011, IPCC 2013). The viability of business-as-usual ways of life will be affected, and transformational changes throughout society at many social and geographical scales are required (Stafford-Smith et al. 2011, O'Brien and Sygna 2013). Yet, the knowledge we already have that can inform transformational change is not being effectively used (O'Brien 2011), and the knowledge and processes of change we do have are limited in their ability to work with the systemic complexity of global problems and to influence action at the rates needed to avoid dangerous climate change (Frame and Brown 2008, Sardar 2010, O'Brien 2012).

New capacities for transformation are needed (Frame and Brown 2008, Sardar 2010, Miller 2011, ISSC 2012, Proust et al. 2012, ISSC and UNESCO 2013, Kläy et al. 2015). This includes approaches to help facilitate transitions, open up thinking, reimagine futures, work with intractable problems, encourage dialogue across diverse groups of people, and provide a sense of empowerment and hope in an era where the extent of the challenges seems overwhelming and debilitating (Frame and Brown 2008, Miller 2011, Ison et al. 2014, Wicks and Jamieson 2014, Kläy et al. 2015). While there are clear overlaps, a focus on transformation is different from resilience, which is often interpreted as adapting to retain current system functions and processes, while transformation is focused on creating significant systemic changes (Walker et al. 2004, Gallopin 2006). In relation to issues like climate change, transformation implies a need to focus on accelerating the development of processes and practices for change (O'Brien 2012). We respond to such calls by outlining a practice called Three Horizons that can be used to help work with uncertain futures in imaginative ways while also retaining important societal features from the present. Interest in Three Horizons has been growing over the last decade, and this approach is increasingly being used in a variety of contexts as a way to help navigate complexity and identify actions to encourage change (e.g., Table 1). While this paper is not based on formalized academic research, it does present the outcomes of cumulative critical reflective practice and experiential knowledge of skilled facilitators of futures-oriented approaches. This knowledge provides new insights about the approach and transformation in practice.

We first explain the need for new approaches for exploring transformative change and then outline the methodological approach taken to articulating the practical knowledge we present. We then describe the Three Horizons approach and the key features that make it useful for transformative thinking and the insights that have emerged from using the approach. Overall, this will be of wide relevance to academics and practitioners interested in learning about how to conceptualize, study, and facilitate the practice of transformation.

\section{The need for new approaches to facilitate transformation}

Working with complexity

Two important challenges related to the practice of transformation are working with complexity and with the future. First, many studies highlight the inherent complexity of contemporary challenges, describing them as "wicked" (Rittel and Webber 1973), working in a "swamp" (Rosenhead 2006), "messy" (Ackoff 1979), "conceptual emergencies" (Leicester and O'Hara 2009), or hyper-complex problems (Scharmer 2009 in O'Brien 2013). These problems, by definition, defy any single way

${ }^{1}$ International Futures Forum, The Boathouse, Silversands, Aberdour, Fife, UK, ${ }^{2}$ Centre for Environmental Change and Human Resilience, University of Dundee, Dundee, UK 
Table 1. Examples where Three Horizons $(3 \mathrm{H})$ dialogue has been used to facilitate change and innovation.

\begin{tabular}{|c|c|c|c|c|}
\hline Case Study & Participants & Background & Aims and Objectives & Process and Role of $3 \mathrm{H}$ \\
\hline $\begin{array}{l}\text { Intelligent } \\
\text { Infrastructure } \\
\text { Systems }\end{array}$ & $\begin{array}{l}\text { UK Govt. Office for } \\
\text { Science \& Technology } \\
\text { Foresight Unit, with input } \\
\text { from a wide community of } \\
\text { experts in government, } \\
\text { academia, and industry } \\
(2006)\end{array}$ & $\begin{array}{l}£ 8 \text { Bn a year invested to maintain } \\
\text { and develop UK transport } \\
\text { infrastructure; } \\
\text { Investments can last } 50-100 \\
\text { years or longer; } \\
\text { Investment needs to meet } \\
\text { conflicting and changing } \\
\text { demands, and be safe and } \\
\text { resilient to shocks }\end{array}$ & $\begin{array}{l}\text { Explore how science and } \\
\text { technology could, over the } \\
\text { next } 50 \text { years, bring } \\
\text { intelligence into } \\
\text { infrastructure to meet } \\
\text { demanding and sometimes } \\
\text { conflicting objectives of } \\
\text { investments for transport } \\
\text { infrastructure }\end{array}$ & $\begin{array}{l}\text { Combination of science reviews, } \\
\text { scenarios, and technology forward } \\
\text { look; } \\
\text { Three Horizons used to link the } \\
\text { components together }\end{array}$ \\
\hline $\begin{array}{l}\text { Challenges facing } \\
\text { rural communities }\end{array}$ & $\begin{array}{l}\text { Carnegie UK Trust, } \\
\text { Commission on Rural } \\
\text { Community Development } \\
\text { (2007) and International } \\
\text { Futures Forum }\end{array}$ & $\begin{array}{l}\text { Long-term pressures on rural } \\
\text { communities, and a firm belief } \\
\text { that a vibrant rural life is a vital } \\
\text { component of an enduring, } \\
\text { balanced, and healthy society }\end{array}$ & $\begin{array}{l}\text { Undertake a comprehensive } \\
\text { consultation on the challenges } \\
\text { and opportunities facing rural } \\
\text { communities across the UK } \\
\text { and Ireland in recent years, } \\
\text { and look ahead to the future } \\
\text { of rural areas }\end{array}$ & $\begin{array}{l}\text { Commission of Inquiry; } \\
\text { Three Horizons used to integrate } \\
\text { material from the Inquiry, develop } \\
\text { a future-oriented "scenario" view, } \\
\text { support strategic visioning, } \\
\text { determine transformative (H2) } \\
\text { actions }\end{array}$ \\
\hline $\begin{array}{l}\text { Transformative } \\
\text { innovation in } \\
\text { education: } \\
\text { "Opening up } \\
\text { Transformative } \\
\text { Innovation," 3H kit } \\
\text { for schools }\end{array}$ & $\begin{array}{l}\text { Scottish Inspectorate of } \\
\text { Schools, Education } \\
\text { Scotland, and International } \\
\text { Futures Forum }\end{array}$ & $\begin{array}{l}\text { Radical changes required in } \\
\text { education needed to prepare } \\
\text { young people for an uncertain } \\
\text { future }\end{array}$ & $\begin{array}{l}\text { Support transformative } \\
\text { innovation with a highly } \\
\text { decentralized, bottom-up, } \\
\text { system-wide approach }\end{array}$ & $\begin{array}{l}\text { Three Horizons strategic } \\
\text { conversations used to develop a } \\
3 \mathrm{H} \text { kit for schools to enable them } \\
\text { to develop their own } \\
\text { transformative initiatives }\end{array}$ \\
\hline $\begin{array}{l}\text { Climate change } \\
\text { community action }\end{array}$ & $\begin{array}{l}\text { Glasgow community and } \\
\text { International Futures } \\
\text { Forum }\end{array}$ & $\begin{array}{l}\text { Conflict in discussions between } \\
\text { meeting outcomes required by } \\
\text { grant givers and values of life } \\
\text { for those affected }\end{array}$ & $\begin{array}{l}\text { To improve the dynamics of } \\
\text { collaboration on climate } \\
\text { change to meet both formal } \\
\text { institutional and community } \\
\text { objectives }\end{array}$ & $\begin{array}{l}\text { Facilitation and framing of } \\
\text { community leader conversations, } \\
\text { using Three Horizon } \\
\text { understanding of horizons as } \\
\text { forms of conscious perspective }\end{array}$ \\
\hline $\begin{array}{l}\text { Transition to } \\
\text { renewable energy }\end{array}$ & $\begin{array}{l}\text { Major European oil and } \\
\text { gas company }\end{array}$ & $\begin{array}{l}\text { Using foresight methods to } \\
\text { explore new paradigm of energy } \\
\text { and the transition issues }\end{array}$ & $\begin{array}{l}\text { To develop a managerial } \\
\text { understanding toward } \\
\text { reframing strategy and } \\
\text { investment portfolio }\end{array}$ & $\begin{array}{l}\text { Scenario method combined with } \\
\text { Three Horizons to develop a } \\
\text { credible research and development } \\
\text { story to guide resource } \\
\text { deployment }\end{array}$ \\
\hline
\end{tabular}

of characterizing them (Rittel and Webber 1973). Nevertheless, they can broadly be considered as possessing dynamic complexity, social complexity (where conflicting values and cultures exist among diverse stakeholders), and generative complexity (where the intended future cannot be addressed only by existing knowledge) (Scharmer 2009 in O'Brien 2013). Contemporary problems can also be characterized as having ambivalent goals, uncertain knowledge, and distributed power (Voß et al. 2007). We broadly refer to these challenges as "complex problems."

Working with complex problems requires approaches that can work with both biophysical and social understanding of systems at interrelated scales (Folke et al. 2010); engage diverse individuals and institutions (Voß et al. 2007); distinguish between and link incremental and transformative change (Wise et al. 2014b); make issues of power and competing values open and amenable to discussion and resolution (Voß et al. 2007, Valorinta et al. 2011); and work effectively through learning, invention, and innovation to help purposely move toward uncertain futures (Voß et al. 2007, Wilkinson 2008:274 in Ramirez et al. 2008). While much progress has been made in understanding complexity (Newell 2012, McGowan et al. 2014) and the different values held by different stakeholders (Christie et al. 2012, Kenter et al. 2015), there are still major practical challenges in working with multiple perspectives and norms (Frame and Brown 2008, Holman 2011, McGowan et al. 2014).

\section{Working with the future}

A second challenge is the need to work effectively with an "incompletely known and uncertain future" (Wilkinson 2008:274 in Ramirez et al. 2008). Futures practices in general support ways of taking decisions in the present that are as well-informed about the future as we can make them, while recognizing ignorance and uncertainty. If there is no uncertainty, then plans and decisions can be made about how to act to achieve the desired outcome. Futures methods therefore connect agency (human decisions, choices, actions, and capacities) (Câmpeanu and Fazey 2014) and intent to irreducible uncertainty about the future context and the effect of our actions.

There are many tools and approaches for working with the future (Van der Heijden 2005, Miller 2011, Hodgson 2012, Mahony 2014, Milojević and Izgarjan 2014, Videira et al. 2014). They can broadly be classified according to how they deal with agency and uncertainty (Fig. 1). First, there are traditional forecasting and planning approaches, such as weather and economic forecasting, that work with low social and generative complexity (bottom left quadrant). In these approaches, the future is generally conceived of as being an extension of the past and is predictable within a set of known sources of variation, even though such changes may be very hard to model or understand. 
Fig. 1. The different kinds of tools for working with the future. The horizontal axis represents the degree of uncertainty about the future; the vertical axis represents the extent to which the tools enhance a degree of agency. Four domains indicate the relative strengths of different tools and approaches. For example, scenarios are generally most useful when the future is highly uncertain, but often on their own have limited capacity to identify strategies for achieving different futures. Roadmaps tend to be most useful in circumstances where there is greater certainty, where they provide clearer directions for change. New pathways approaches are emerging, which aim to enhance agency in situations of high uncertainty. The arrows indicate that some scenario approaches, depending on how they are applied, also can work well in the high uncertainty and high agency domain, and that many existing pathways approaches are aligned more closely with roadmaps.

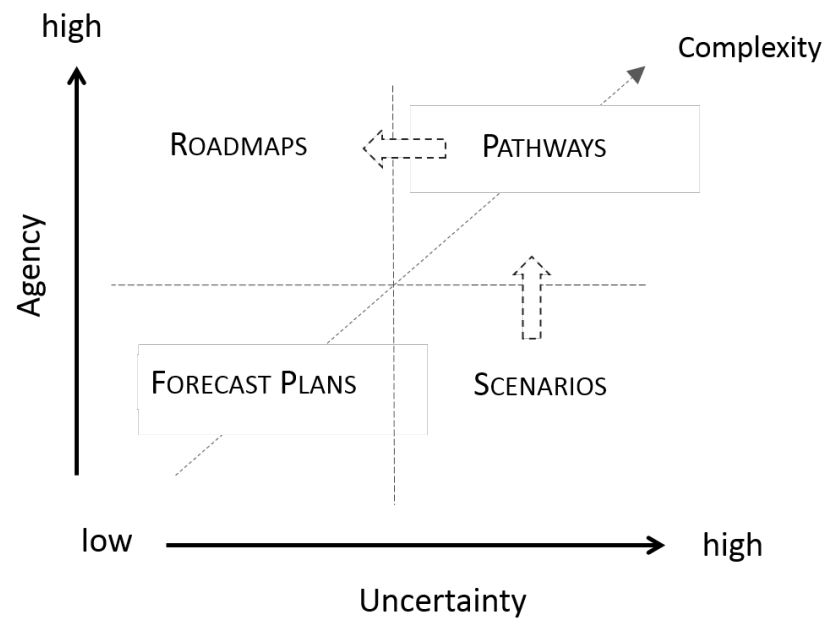

Second, there are approaches that generate high agency but which work best in situations where the uncertainty can be managed by bringing it fully within the scope of the actors involved to collectively assert their agency (top left quadrant). This includes roadmaps, which are a strategic planning exercise focused around a complex issue that involves step-by-step progress and learning. Roadmaps usually involve bringing together expertise to assemble paths toward the future in relation to intermediate goals, and aligning intent among many parties to direct resources and activity toward shared goals (Saritas and Aylen 2010). In technology, the classic case is the semiconductor industry roadmap, which was based on the premise that computing power would increase exponentially (Moore 1965). Through continued resourcing and shared effort, the roadmap helped ensure the future was realized. The roadmap orientation to the future is therefore about creating a strong sense of shared agency while also reducing uncertainty in more manageable ways through shared research and development. The outcome is usually a single roadmap that characterizes the path of action and learning the participants intend to pursue. This provides the agency but does not allow significant space for the emergence of new and uncertain future conditions that might require going down new paths.
Third, there are approaches that work well with uncertainty but do not necessarily result in high degrees of agency in the same way that roadmaps do (bottom right quadrant). This includes scenarios. These are perceptual tools for exploring uncertainties in an unknown future; they are usually developed as a small set (two to four) of plausible and structurally different futures (Peterson et al. 2003, Van der Heijden 2005). Although scenario approaches can generate agency (see next paragraph), scenarios do not by themselves reveal strategies, and are instead part of an input to a strategy process (Ramirez and Van der Heijden 2007). Scenario planning therefore actively seeks out sources of uncertainty and keeps them visible in ways that challenge the assumptions on which current activities are based. The output of a scenario planning project is a set of different scenarios that highlight critical uncertainties by using distinct stories or visual representations of alternative futures.

Roadmaps are concerned mostly with coordinating social complexity, whereas scenarios are theorized as exploring and reperceiving the dynamic complexity and uncertainty of the future (Ramirez et al. 2008) (Fig. 1). This leaves an important space for approaches that bring agency into the full domain of future uncertainty (top right quadrant, Fig. 1). A variety of scenario planning approaches are used for this, such as normative, transformative, and participatory approaches, those which combine exploratory and normative scenarios, and those that use backcasting to develop normative strategies within a scenario framework (Ogilvy 2002, Bell 2003, van Notten et al. 2003, Voß et al. 2007, Kok et al. 2011, Kahane 2012). Privileging agency of participants is a critical aspect of such futures work (Ogilvy 2002, Bell 2003, Weisbord and Jasanoff 2010). Increasingly, however, a new set of approaches, known as pathways approaches, attempt both to deal with complexity and provide agency (Fig. 1). There are many different interpretations of pathways approaches (Leach 2008, Haasnoot et al. 2012, Wise et al. 2014b, Fazey et al. 2015), but essentially they aim to help work toward new futures in a semiexploratory way (e.g., by identifying different routes and paths) but without the specificity of a single roadmap that assumes the ability to control all the sources of complexity. Many of the existing pathways approaches are, however, highly technical, and work on identifying key decision points and critical junctures in ways that do not easily translate well into the messy and subjective world of complexity in practice. Such pathways approaches are often more similar to roadmap techniques, and have an underlying assumption of well-understood systemic causality and an intention to identify linear directions for establishing new futures.

Currently, there are limited futures-oriented approaches that simultaneously work with complexity, diverse perspectives, and values and still provide space for the kinds of imagination, creativity, and emergence necessary to go beyond incremental or marginal change. While there are exceptions (Burns 2007, Burns and Worsley 2015), many existing approaches are complex and technical, and there is a need instead for approaches that can help generate futures literacy among broad constituencies of participants in transformative change (Miller 2011, O'Brien et al. 2013). We outline a relatively new approach called Three Horizons practice, which was first introduced as an analytic lens for foresight work (Sharpe and Hodgson 2006, Curry and Hodgson 
2008). Three Horizons practice supports thinking and dialogue about transformation, and while it has been used in many contexts (Table 1), as yet, there has been limited critical explanation and examination of the approach.

\section{METHODOLOGICAL APPROACH}

We outline the Three Horizons practice to encourage further and wider debate about the facilitation of transformative change. The research approach used to generate the insights, however, does not conform to traditional methodological approaches used in academia. Instead, it is an articulation of the extensive experience the authors have gained through developing and using Three Horizons in purposive reflective practice.

Researchers tend to focus on epistemic forms of knowledge, which is logically built up and then applied back to practice (Aristotle 2004). Such knowledge is teachable and often represented as a set of principles or guidelines. Such principles are used to illuminate an issue and inform judgment, but they do not prescribe action. This requires more practice-oriented forms of knowledge, such as techne or "know how" knowledge and phronesis (practical wisdom)(Aristotle 2004). The latter involves knowing how to act and reflect appropriately to achieve "good ends" (Shotter and Tsoukas 2014). Techne and phronesis are usually concerned with the particulars of the situation and what is experienced (Van De Ven and Johnson 2006, Shotter and Tsoukas 2014), such as the knowledge applied by expert facilitators when working with different groups of people, solar technicians installing solar panels in different circumstances, or doctors working with different patients. Eliciting such knowledge is challenging because the process of elicitation separates the knowledge from the person in which it is embodied and the context to which it is applied (Barab and Plucker 2002).

Epistemic knowledge alone cannot facilitate the kinds of change needed to address contemporary societal challenges, and other forms of practical knowledge are required. Yet, despite this need, techne and phronesis are not well recognized by academics. This results in the theories of pure researchers dictating actions of those in practice (Pryjmachuk 1996), or practitioners ignoring theoretical insights because they do not find them useful (Rolfe 1998). Standard attempts to close the perceived "gap" between academia and practice then usually involves academics trying to develop better strategies for dissemination and greater use of research findings, which makes the gap wider by suppressing professional judgment and forcing practitioners to use ill-suited research findings (Rolfe 1998).

We therefore take a different approach to that normally presented in academic journals. We aim to articulate how Three Horizons practice is approached and used (techne), and discuss the insights about change and transformation that have emerged from facilitating Three Horizons practice, which help make judgments about "good ends" (phronesis). These insights have emerged from our collective practical knowledge of learning how to apply the approach in diverse contexts in combination with many other approaches, and from the facilitation of groups trying to make sense of, and work with, complexity. Together, we have approximately 90 years of experience in facilitation of futures and strategy thinking and about 35 years of facilitating Three Horizons. This includes using the approach in about 180 different situations, and training 135 people to use the approach. We have also spent considerable effort in learning from and about the approach, innovating, and reflecting on its outcomes, including having numerous discussions that have led to refinements and improvements, and ultimately this paper.

Importantly, it is not our intention to present this work as an academic piece that "tests the effectiveness" of Three Horizons, presents "evidence" of its value, or promotes the approach above other useful approaches. We also do not suggest that the work meets notions of rigor applied in the social sciences that are used to develop epistemic knowledge, and some may therefore label this paper as no more than a "practice note." Instead, we have worked carefully to find the best way to articulate what we think we know from reflecting on the facilitation of Three Horizons. The work can therefore be considered as the outcome of actionoriented, first-person inquiries by practitioners (Reason and Bradbury 2008), and our intention is to lay a foundation for others to apply Three Horizons, develop their own practical understanding, and come to their own conclusions in their own settings and contexts about the relevance and validity of the approach. This paper should therefore be viewed as a set of propositions about (1) the practice of Three Horizons, and (2) the more general insights about the nature of transformation that have emerged from its practice. These propositions can then be examined in further detail by using more deductive methodologies, such as through critical and reflexive action research and comparative case studies (Ison et al. 2014).

\section{THREE HORIZONS AS A PATHWAYS PRACTICE}

\section{Three Horizons framework}

In this section, we outline how Three Horizons practice is often used. The practice typically involves a facilitated conversation with diverse stakeholders to assist sense-making and strategic action. It can be facilitated through multiday workshops or as short exercises to complement other activities, including working in ways that are complementary to other approaches and tools. Three Horizons practice uses a simple framework that can easily be communicated in a few minutes. This framework includes three lines, with each line representing a system or pattern in the way things are done in a particular area of interest (e.g., how an organization operates, particular values in society, or the use of certain forms of technology) (Fig. 2). The horizontal axis represents time stretching into the future from the present, and the vertical axis indicates the prevalence of each pattern in a relative way. The framework represents three different patterns: an established first horizon pattern giving way over time to an emerging third horizon, via transitional activity in the second horizon.

The first horizon $(\mathrm{H} 1)$ : This represents the way things are done now, generally called "business as usual." Society relies on stable patterns for the everyday business of life, and most change is incremental within these familiar patterns and serves to reproduce and reinforce them. The starting point of a three horizon conversation is the recognition that the first horizon pattern is losing its fit with emerging conditions. 
Fig. 2. Three Horizons. "Prevalence" refers to the extent to which a particular pattern dominates the issue of concern (e.g., way of doing things, use of a particular technology, set of values). These patterns change over time. H1 is a current, declining, pattern. $\mathrm{H} 3$ represents an emerging future pattern. $\mathrm{H} 2$ is the turbulent domain of transitional activities and innovations which people are trying out in response to the changing landscape between $\mathrm{H} 1$ and H3. Importantly, each way of doing things is present at all times, albeit to a greater or lesser extent. $\mathrm{H} 2$ - and $\mathrm{H} 2+$ highlight that innovations emerging in $\mathrm{H} 2$ can either be subsumed back into $\mathrm{H} 1$ or go on to create the space for, and emergence of, $\mathrm{H} 3$.

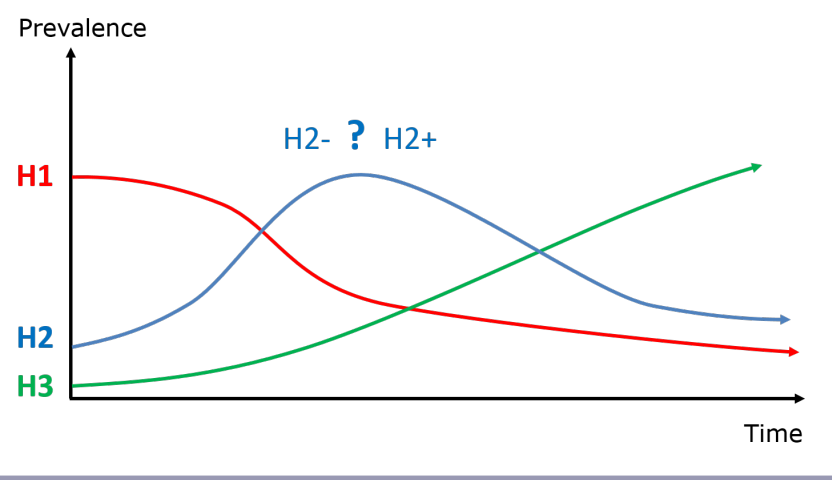

The third horizon (H3): This represents the emerging pattern that will be the long-term successor to the current first horizon. It is appearing and growing on the fringes of the present system, and developing new ways of meeting the emerging conditions and possibilities. Although some dominant pattern will eventually emerge, in the process of developing a three horizon map, many different views of the future will be present and contested.

The second horizon (H2): This is the turbulent domain of transitional activities and innovations that people are trying out in response to the changing landscape between the first and third horizons. This second horizon is important, as it provides the disruptions for more radical $3 \mathrm{H}$ systems to emerge. Some innovations $(\mathrm{H} 2+)$ will help extend the $\mathrm{H} 1$ systems and facilitate the emergence of H3 systems. Many innovations will fail, and others (H2-) will be absorbed back into the H1 systems and contribute only to marginal or incremental change. A good example are photovoltaic cells (solar panels). They have significant potential to generate a revolution in the power relations between traditional consumers and producers of energy. Consumers can become producers, and create the conditions for radical and transformative innovations in storage capacity and localized production that remove market dominance of existing large energy companies (Schleicher-Tappeser 2012). Whether the H2 innovations become subsumed or controlled by existing energy generation patterns and actors or go on to generate transformative outcomes remain to be seen, and will depend on an array of social, political, and technological factors, including the extent of the ability of different actors to influence regulatory demands.

\section{The practice of Three Horizons}

Although Three Horizons has a simple framework, it can be thought of as a practice rather than a theory, concept, or idea. This is because it involves a facilitated process with a diverse group of stakeholders to map out how different patterns change over time. It is the experience of being involved in the process that helps participants reframe their understanding of the relationship between the present and the future. This makes it different from detailed concepts and frameworks, such as multilevel perspectives on socio-technical transitions, technological innovation systems, or the sociology of expectations (Borup et al. 2006, Geels and Schot 2007, Bergek et al. 2008), which are used predominantly as explanatory abstractions and heuristics. The simple structure of Three Horizons makes it highly accessible to diverse participants, including children (e.g., Leicester et al. 2013), and allows for the incorporation of different dimensions of existing theories (e.g., multilevel perspectives) when required.

There are usually five key steps involved in the practice of Three Horizons. They are illustrated through an example (Fig. 3) where a local authority sought to explore how to transition toward and implement a new Curriculum for Excellence in Scotland (CfE). This aimed to be a radical departure from existing curricular and educational approaches. In this case, the Three Horizons dialogue process assisted thinking within the local authority about how to meet the challenges and opportunities within the emerging policy framework while continuing to deliver effective education through the transition period (Fig. 3). The following steps were used to explore this transition:

Step 1: Examining present concerns. A three horizon conversation begins by bringing the issue of concern into view and describing the ways in which the current way of doing things is seen to be losing its fit with emerging conditions. In the CfE example, the emergence of personalized, adaptive teaching technology, alongside pervasive digital delivery offered a multitude of new ways to structure individual learning paths. This required a complete rethink of the role of the teacher, classroom, and school to make best use of emerging opportunities and changing context.

Step 2: Exploring future aspirations. This involves examining the third horizon, where visions, aspirations, and possibilities for the reality that will emerge over time are explored as a replacement of the first horizon. In CfE, the emerging technologies offered possibilities to link the school and home in many more ways to support learning, and there were aspirations for teachers to be learners, and for children to have greater responsibility and ownership of their learning.

Step 3: Exploring inspirational practice in the present. The second step generally merges with the third step, which is to identify "pockets of the future in the present," which are concrete examples of where new ways of doing things are visible at the margins of the mainstream first horizon systems. In CfE, this involved both looking to existing practices locally and examining the huge variety of educational systems globally and the different approaches they provide.

Step 4: Innovations in play. This step considers the second horizon, which is viewed as the realm of transition between the first and third horizons, and innovations are identified that can 
Fig. 3. An example of the outcome of using Three Horizons as a process to structure dialogue developed through working with a local authority in Scotland to transition to the Curriculum for Excellence. The black numbered boxes represent the order in which different aspects of the Three Horizons are explored. The dark grey shaded boxes were items given to participants by the facilitators to trigger thinking about how things might change in the future. These prompted wider discussion and are represented by the lighter shaded boxes. The figure is an anonymized version with only a sample of the items included.

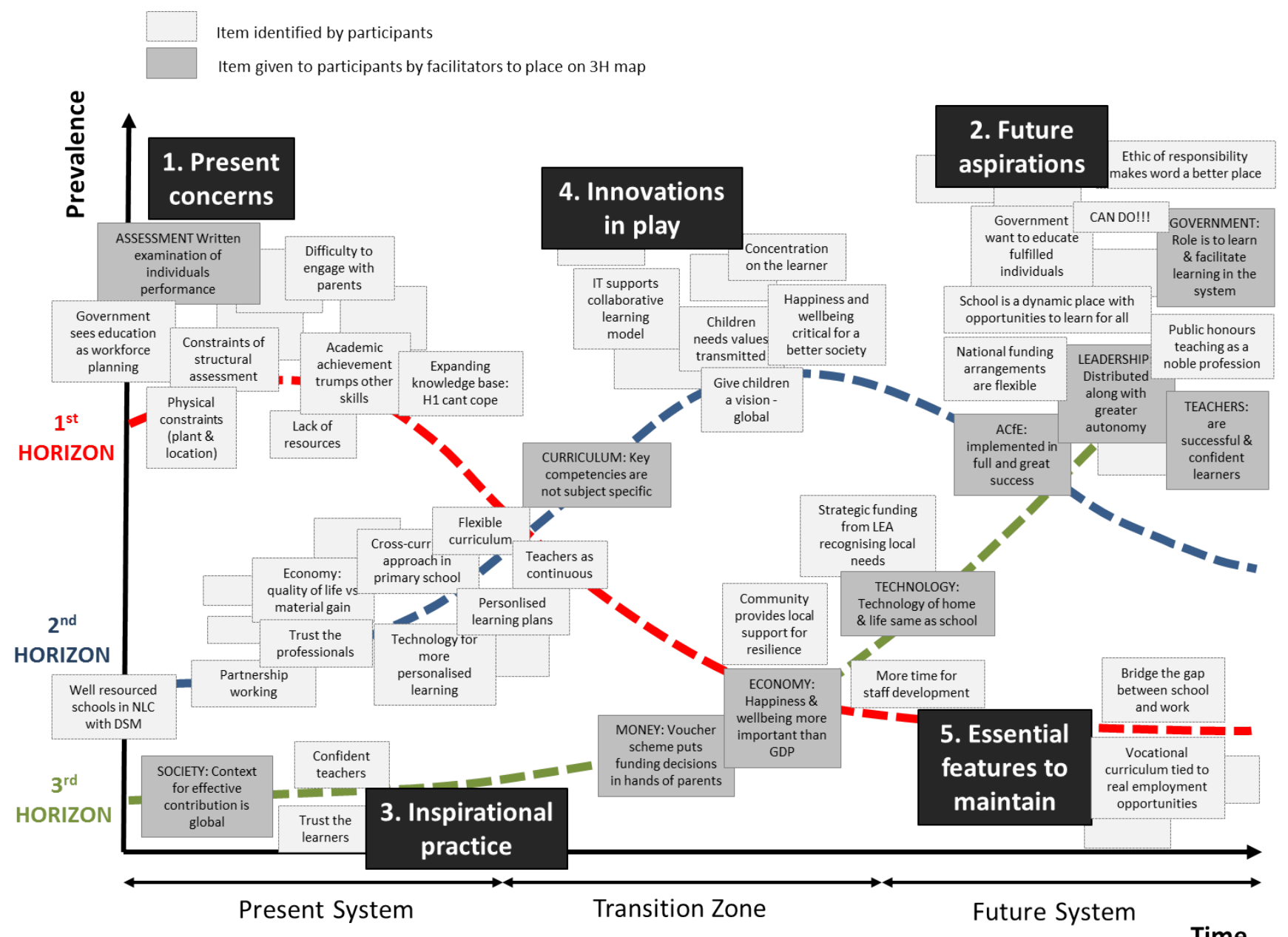

be seen to be going on in response to the failings of the first horizon and the possibilities of the third. For example, in CfE, a huge number of new players were identified, coming from both inside and outside the education system, who are introducing new digital platforms such as MOOCs (Massive Open Online Courses). These have gained a great deal of attention and are evolving rapidly in ways that open up further opportunities in the $\mathrm{H} 2$ space. The outcome of many of these disruptive innovations is not yet clear.

Step 5: Essential features to maintain. The final step draws attention to those aspects of the old system that will persist into the future within the context of the new dominant system. These are often examined as the key or desirable elements that need to be retained.

Finally, a number of additional steps are typically added to the process that make the move from sense-making to transformative action, such as examining trade-offs and dilemmas, and how some $\mathrm{H} 2$ innovations can serve to prop up $\mathrm{H} 1$ systems or go on to provide new space for emergence of $\mathrm{H} 3$ systems, and how the participants relate to acting on these possibilities. The specific process is highly contingent on the project context, but in general, the aim of a $3 \mathrm{H}$ conversation is to get into action by identifying actions in the second and third horizons that will take a step along the pathway of change. These issues are covered in the next section as part of the discussions about the useful features of Three Horizons practice.

\section{USEFUL FEATURES OF THREE HORIZONS PRACTICE}

A simple framework to help work with complexity

We have found that one of the most useful aspects of Three Horizons is that it provides a simple structure for working with complexity around which dialogue about change from one pattern to another can occur. While this is not as comprehensive as deeper 
explanatory theories and approaches to change (Waddock et al. 2015), a deep explanatory framework is not the intention. Instead, we have found that the pre-given framework is simple enough to allow participants to add their own issues and perspectives, help them begin to make sense of the complexity in a holistic way, avoid constraints in thinking about how progressive change may unfold, and explore the role of different components in a particular change context or situation. We have also found it helpful to avoid deep dialogue around concepts like transition, resilience, or transformation, which in our experience often creates inertia and inhibits action. Unlike scenario planning, we have also found that the Three Horizons framework avoids the need to create a unique structure for each particular issue or context. Creating a Three Horizons map can be done in only a few hours or through much longer sessions. While developing deep understanding takes time, a short discussion can give a preliminary grip on a situation which then motivates further enquiry and more detailed explorations to help shape the implementation of the actions identified.

\section{Development of future consciousness}

While it is common to represent societal change as succeeding Scurves (Perez 2004, Tibbs 2011), this does not draw attention to the fact that change always originates in the present (Curry and Hodgson 2008). In the practice of Three Horizons, a key step is to identify examples of the third horizon in the present (pockets of the future in the present), and consider how this new pattern can emerge through the transitional second horizon. We have found that Three Horizons can help participants situate the present moment in relation to the future. This is because it helps them regard each horizon as a quality of the future in the present, with each horizon characterizing a distinct way of acting in the present with a qualitatively different relationship to current and future patterns. The first horizon is characterized as a "managerial" mindset, which keeps things going in familiar ways; the second is the entrepreneurial orientation that seizes an opportunity; and the third is the visionary outlook that holds an imagined future in mind and steers toward it. In this sense, our experience suggests the approach can help different actors bring all three orientations to the future into view and encourage participants to work with these horizons in a flexible waymoving from holding any one orientation as a fixed mindset to using them all as alternative perspectives.

This step into an explicit awareness and use of all three perspectives can be thought of as "future consciousness," or an awareness of the future potential of the present and how the future emerges from what is done now (Sharpe 2013). This relates to calls for "effective future-mindedness" (Ramirez et al. 2008) or futures literacy (Miller 2011). Developing future consciousness highlights that effective transformational practice needs to engage people in developing their own role in shaping the future in a reflexive and reflective way, so that they can take responsibility for the process of making transformation happen.

\section{Distinguishing between incremental and transformative change}

Being able to distinguish between actions that generate incremental or transformative change is important for more effectively transitioning to new futures (Wise et al. 2014a). Yet, this is difficult because transformation is often apparent only after it has occurred. We have found that Three Horizons helps participants explore dominant patterns of activity and more transformative ways of doing things. Through the facilitation of Three Horizons practice, participants begin to recognize that the first horizon is not static and that dominant pattern(s) of activity are actively maintained and reproduced by social processes. That is, invention and innovation are always going on in which the system renews itself and gets "better" in its own terms, such as computers getting faster, drugs getting better, guns getting more lethal, and political parties producing their manifestos. Such patterns are actively maintained by many social actors: those who produce them, use them, and govern them with tacit and explicit rules, laws, and norms.

An example is the outcomes of many attempts in practical domains to enhance resilience. While origins of the concept in environmental domains highlight the importance of adaptability and flexibility in social and ecological domains as a key source of resilience (Holling 2001), the concept of resilience is increasingly used in diverse ways (Chandler 2013). In particular, it can often be interpreted as a process for maintaining the status quo rather than for creating more systemic levels of change or in ways that do not acknowledge ecological feedbacks from human actions (Whiteman et al. 2004, Pelling 2011). Examples include finding more flexible ways to keep motorways open or airplanes flying when societies are faced with various natural and human hazards. This reinforces or enables environmentally unsustainable economies, even though the perseverance of heavily consumption-based economies continues to influence underlying causes of increasing threats from natural hazards through climate change. Such well-intentioned approaches to resilience prop up existing systems in ways that early proponents of social-ecological resilience sought to avoid (Holling and Meffe 1996, Holling 2001, Folke 2006). In Three Horizons practice, these kinds of adjustments might be interpreted as sustaining the first horizon political-economic structures. In contrast, transformation is then understood as requiring renewal of those structures in the transition to the third horizon. This interpretation of transformation is consistent with many of those in the academic literature (Walker et al. 2004, Gallopin 2006).

By exploring first and third horizon patterns, we have found that participants begin to appreciate how active processes of innovation can often help maintain and reinforce current systems in ways that paradoxically limit change, and result in only minor incremental advances over time. Working with the first horizon also highlights how incremental changes that maintain this horizon can result in "fixes that fail." For example, an issue explored in the Intelligent Infrastructure Systems foresight project (Table 1) was the need to transition to sustainable forms of transport with greatly reduced greenhouse gas emissions. In this case, participants came to the conclusion that the first horizon transport system needed to continually increase the provision of transport infrastructure to keep up with increasing demand. Yet, the gains from greater efficiencies that emerged from new incremental innovations were generally being lost when the use of transport in the system overall increased. This highlighted that transformation to a fully sustainable system therefore involved not only major transitions to clean energy but also ways to contain demand, such as through new patterns of mobility achieved by alternative forms of urban design and different work and leisure social practices. Through contrasting first and third horizon 
patterns, participants were then able to consider a new system that was a better fit to emerging conditions (e.g., a low carbon economy) and that included changes in the underlying assumptions that put boundaries on incremental change. In our experience, practicing Three Horizons can therefore help participants distinguish between incremental and transformative change, but in a way that enables them to bring these aspects together and consider the transitions necessary to move from one form of action to another.

\section{Making power explicit}

Deliberate societal transformation involves intentionally trying to direct patterns of change. This requires exploring who has the power to resist or bring about change, to what extent change can be created, and the relationships between different actors (Hatt 2013, Geels 2014). Through facilitating Three Horizons, we have found that it can help participants explore issues of power in two main ways. First, through focused discussions it assists practitioners to identify how different actors can most usefully influence change. For example, in the Intelligent Infrastructure Systems project (Table 1), it became apparent through discussions that an individual citizen can do little to influence the availability of electric cars beyond exercising their consumer choice, but they might join a green lobby group to campaign for change; an entrepreneur can raise capital and pioneer innovative technologies but cannot do much to put in place needed infrastructure, and they need pioneering citizens as customers; or a government transport minister has power to influence policies but might need the active support of industry groups and lobby groups to drive change and shift social norms around the use of cars.

Second, through facilitating the practice of Three Horizons, we have found that the approach can help participants explore whether or how society is organized to manage the processes of moving toward the third horizon depending on the nature of the societies in which they live. For example, democratic societies have established processes for the orderly transfer of power, and can renew their laws and the constitution that governs those lawmaking processes. Other societies may be unable to transfer power and manage change without violent conflict, collapse, and renewal in the governance structures themselves. In these cases, it may take acts of profound courage to challenge the power of the status quo, and the outcomes will be violently contested. Similarly, in developed market economies, affairs have been organized so that there are distinct policies for governance of the established businesses of the first horizon, venture investment for the second, and exploratory research - often government funded through universities - for the third. Most societies have some policies to limit the power of the first horizon actors, such as monopoly rules and preventing cartels (Ma 2013), but powerful companies can buy up or suppress threatening innovations (Stanford 2012, Gerschel-Clarke 2013, Geels 2014). Incumbents also have significant power and access to the processes of government, and can often achieve a degree of regulatory capture, which enables them to exert influence over how new possibilities are framed, or resist legislation they perceive as damaging their interests (Geels 2014). Differences in the way societies are organized, therefore, have different effects on the way in which renewal occurs or can be precipitated.
By working with Three Horizons, we have found that the processes that support or resist change can be made amenable to discussion, which can help participants think about how to manage the transitions and change those processes. This does not mean that everyone will necessarily agree on what the third horizon and pattern of renewal should be. Quite the reverse: the practice offers a way to identify where there are disagreements and help inform which actors need to be convened to support the process of change and renewal. We refer to this process as "Convening the Future" (Sharpe 2013). This relates directly to the observations of both Weisbord and Jasanoff (2010), in their Future Search method, and Kahane (2012), in his Transformative Scenario Planning method, that it is crucial to get the "whole system" in the room. Three Horizons does not take a view on whether the whole system must be convened, since often change is brought about by challengers outside the system, but it does support the enquiry and facilitate constructive dialogue in systemic ways among those who view the world through particular horizon perspectives (see Framework for dialogue among different actors).

\section{Exploring the management of transitions}

In our experience of using Three Horizons, we have found that it helps maintain focus on the management of transitions. Consideration of the first horizon brings out the initial scoping of the issue and the indicators of stress and loss of fit that are motivating the need for change. Discussing the third horizon then allows participants to drop the assumptions that would keep responses within the incremental range of the first horizon system. This frees participants to explore a wide range of transformational possibilities by drawing both on what they see out in the world as responses to the changing context and their own visions and aspirations. The exploration of the second horizon is then placed between these two as the zone of transition between the existing systems of the first horizon and the emerging or imagined third. This enables discussions to focus on managing the transitional process from current to transformative ways of doing things. In the Intelligent Infrastructure Futures example (Table 1), transport policies for incremental improvements in efficiency (extension of the first horizon) were contrasted with policies to transform mobility patterns to reduce demand (third horizon transformation), which enabled a focus on second horizon policies that would help the third horizon changes to emerge.

We have found two techniques for exploring the second horizon transitional space to be helpful. The first is the distinction between "H2 plus" $(\mathrm{H} 2+)$ innovations, which lead on to the third horizon, and "H2 minus" (H2-) innovations, which may "prop up" the first horizon. Designating innovation as $\mathrm{H} 2$ plus or minus is not absolute but something that can be explored. For example, in the Intelligent Infrastructure Futures project (Table 1), one of the issues identified was how new technologies would interact with the demand for transport. On the one hand, transport innovations that increase speed and efficiency were considered to be useful for relieving some problems in the short term but still increased demand and emissions in the longer term. This then represented an $\mathrm{H} 2$ minus capture of the innovation by the $\mathrm{H} 1$ patterns of mobility. On the other, innovations that link transport services to new urban planning and shifts toward active transport (walking and cycling) were identified as likely being able to gradually transform mobility patterns toward a third horizon of sustainable 
transport-an $\mathrm{H} 2$ plus intervention. This does not mean that $\mathrm{H} 2$ minus interventions are inappropriate and there is no a priori "right" view of interventions. Nevertheless, our experience suggests that considering the role of innovations through Three Horizons can help participants identify which ones are more likely to lead to transformation.

The second technique for exploring the second horizon transitional space is dilemma thinking (Hampden-Turner 1990, Höijer et al. 2006). The central idea is that while decision situations often appear to be exclusive choices, they can sometimes be more helpfully viewed as two competing sets of values where both must be respected (Leicester et al. 2013). For example, businesses have a dilemma of needing to optimize the current business while investing in innovation for future revenue. If either is chosen to the exclusion of the other, the business will eventually fail.

Through facilitating Three Horizons we have found that discussions about change often become polarized between the first horizon status quo, seen as "bad," and the new/desired third horizon system, viewed as "good." In any real world situation, however, there will be much in the existing system that needs to be carried forward into the new, and aspects of the new that need to build on contributions from the first rather than to fully reinvent or ignore them. In the Carnegie case (Table 1), for example, participants identified historical patterns of land use and ownership that have been both barriers to, and enablers of, new patterns of use. This included, for example, increasing trends toward rural estate owners effectively becoming farmers of wind or water alongside more traditional agriculture and forestry, and picking up rich subsidies in the process. Dilemma thinking addresses such challenges by taking the two sides of a polarity and presenting them orthogonally, framing a space in which there can be dynamic movement toward synthesis and resolution (Fig. 4). Dilemmas are therefore not "solved," but constantly "resolved" through experimentation, feedback, learning, and creative innovation. Overall, approaches such as distinguishing between $\mathrm{H} 2$ plus and minus, and dilemma thinking, complement other aspects of Three Horizons practice to help participants identify the kinds of transitional changes that need to be put into place to achieve transformation.

\section{Framework for dialogue among different actors- the three horizon "voices"}

Participants involved in Three Horizons practice have indicated that one of the most useful aspects of the framework is that it helps improve the social dynamics of transformative conversations. Through our extensive experimentation and reflection on the practice, it seems that this occurs because Three Horizons (1) is easily communicated and provides opportunities for sense-making in a pragmatic way, (2) enables participants to help identify their own role toward either maintaining the existing systems or pioneering new ones, and (3) encourages those involved to understand the different roles and positive contribution of each horizon. The second and third points are made possible when participants start to move from inhabiting a horizon as a fixed mindset to using it flexibly as a perspective. Here, the first horizon represents the mindset of a "manager" responsible for keeping business-as-usual systems going; i.e., "keeping the lights on" or "ensuring the plane can still stay airborne while being redesigned." The third horizon is the mindset of the "visionary," who imagines new possible futures and tries to achieve them through pioneering actions. Many of the ideas of the visionary are likely to be considered too far beyond current thinking to be widely accepted in the present, even though they may eventually become the new normal in the future. The second horizon is the mindset of the entrepreneur, who acts opportunistically to "seize the day" and bring new ideas and innovations into reality. In discussions about complex issues involving change, participants often bring a particular mindset, and implicitly view the others in adversarial ways (Table 2).

Fig. 4. The space of dilemmas between the values of Horizon 1 and Horizon 3 in the Carnegie case study. In this space, policies and experiments are used to progress towards transformation.

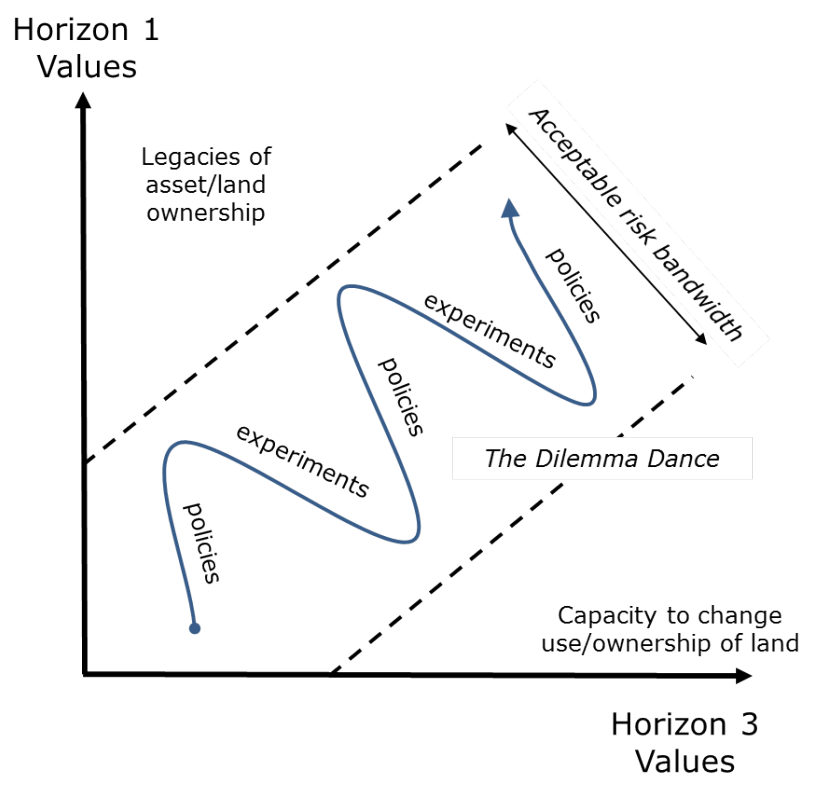

We have found that by using Three Horizons, participants become aware of the different value and role of each horizon and their associated mindsets, and that this greatly reduces many sources of tension and conflict. Initially, those responsible for the first horizon systems that are important for daily life, who have to meet ever greater obligations for accountability, transparency, and so on, often regard the third horizon visionary as an irritating and unrealistic nuisance (Table 2). The third horizon pioneer, in contrast, will often regard the first horizon manager as a dinosaur who is blocking change (Table 2). Yet, when each party is able to see that if no one keeps the current system going, the future cannot be resourced, and that if there is no action toward future needs, the existing system will collapse, then a much more fruitful discussion becomes possible.

A concrete example from using Three Horizons was in the Carnegie case (Table 1). The commissioners were exposed to a diversity of views and perspectives on the future and were able to visit examples of innovative, nonmainstream practice. They realized at that point that they needed help to make sense of the mass of everything they had seen and the numerous perspectives of individual commissioners. The Three Horizons approach enabled the different perspectives and variety of evidence to be 
Table 2. The different outlooks of the Three Horizons toward each other, both as a negative mindset and a positive perspective in the form of words that have been used in real sessions (based on text produced by Ian Page, personal communication). This table is often reported to be one of the most useful things people get from using Three Horizons.

\begin{tabular}{|c|c|c|c|}
\hline $\begin{array}{l}\text { Looking from } \\
\text { this Horizon }\end{array}$ & $\begin{array}{l}\text { Looking at this } \\
\text { Horizon }\end{array}$ & Negative (Mindset) & Positive (Perspective) \\
\hline \multirow[t]{4}{*}{ Horizon 1} & Horizon 1 & Competitor. Beat or take over. & $\begin{array}{l}\text { Useful infrastructure. Potential allies in lobbying for shared } \\
\text { interests, etc. }\end{array}$ \\
\hline & Horizon 2 & $\begin{array}{l}\text { Parasite of potential investment. Watch and } \\
\text { monitor. }\end{array}$ & $\begin{array}{l}\text { Source of abundant ideas. Improvement. Changes scope of what } \\
\text { can be done. }\end{array}$ \\
\hline & Horizon 3 & Fanciful and irrelevant. Ignore, or kill to prevent & Hope for the future. Possibility of renewal. \\
\hline & & $\begin{array}{l}\text { momentum building that would challenge } \mathrm{H} 1 \\
\text { dominance. }\end{array}$ & Not challenging $\mathrm{H} 1$ role: relates to more of my life than $\mathrm{H} 1$. \\
\hline \multirow[t]{3}{*}{ Horizon 2} & Horizon 1 & $\begin{array}{l}\text { Slow-moving dinosaurs. Obstructive. Get out of } \\
\text { the way! }\end{array}$ & $\begin{array}{l}\text { Holding the "innovator's dilemma." Destination for innovation. } \\
\text { Arena of action. Source of support and ways to scale up. }\end{array}$ \\
\hline & Horizon 2 & Competitors for resources. & Allies in creating momentum. \\
\hline & Horizon 3 & Impractical. & Inspirational. Source of ideas and visibility. Sense of direction. \\
\hline \multirow[t]{3}{*}{ Horizon 3} & Horizon 1 & Massive error and liability, barrier to progress. & $\begin{array}{l}\text { Potential resource when unlocked. Skills that can be redeployed } \\
\text { - to scale. Valuable heritage and gains to be protected. }\end{array}$ \\
\hline & Horizon 2 & $\begin{array}{l}\text { Obstructive compromise. They are misusing our } \\
\text { vision. }\end{array}$ & $\begin{array}{l}\text { Potential allies. Promising practice, stepping stone. Changes } \\
\text { scope of what is possible. }\end{array}$ \\
\hline & Horizon 3 & Vision competitors: debate vigorously. & $\begin{array}{l}\text { Extends the debate beyond the present; brings deeper issues of } \\
\text { value into play. }\end{array}$ \\
\hline
\end{tabular}

held and appreciated at the same time. An important contribution was the way the approach revealed that commissioners who were initially stereotyped as entrenched in one specific horizon volunteered significant perspectives from other horizons, thus dissolving many of the earlier disagreements. This shows how Three Horizons legitimizes each of the different perspectives and highlights the value of each. In our experience, this can result in a shift from holding a horizon as a mindset to using it as a flexible perspective on the situation. This allows a shift into future consciousness that is the key enabling feature of Three Horizons. In summary, Three Horizons helps create a common language where participants quickly find it very natural to start talking of issues and situations in terms of the "horizons," which in turn, helps participants with significantly different values and ideologies work together more effectively.

\section{DISCUSSION AND CONCLUSIONS}

The key qualities of Three Horizons practice, based on our experience of facilitating the approach, can be summarized in three main ways. First, it seems to help people begin to make sense of complex situations through seeing the world in patterns in a way that is relevant to their concerns and their aspirations for change. Second, it appears to allow participants to "put themselves in the picture" and to relate their own role in bringing about change to that of other actors. Finally, by moving from their own mindset to a wider perspective of all three horizons, our experience suggests that participants can improve the quality of future-oriented dialogue between those who have responsibility for the present pattern and those seeking a path of transformation to the future. Through experiencing such dialogue, participants often express that they have experienced a renewed sense of hope brought about by greater understanding of how actions in the present can contribute to emerging futures (Sharpe 2013).
Three Horizons therefore seems particularly useful for supporting a rapid entry into a future-oriented dialogue on diverse topics, with a language that is easily grasped. But like all approaches, it has limitations. Personal communication with scenario planning facilitators has indicated they find it useful to use the approach as a scoping tool at the start of a project and to shape strategic action at the end, while using scenario planning to explore the uncertainties within and between horizons. Other tools and practices are therefore sometimes needed to develop deeper insights, such as systems mapping to develop understanding of critical relations and feedbacks (Fazey et al. 2011); scenarios to structure third horizon uncertainties (Peterson et al. 2003, Saritas and Aylen 2010); multiscale perspectives to examine transitions in more depth (Geels and Schot 2007, Geels 2014); and dilemma thinking to help work with trade-offs (Höijer et al. 2006). In a recent exploration of the future of carbon pricing for an international institution that had convened a high level expert group, Three Horizons was used primarily to frame the problem and identify critical unknowns. These unknowns were then explored in greater detail using dilemma thinking and scenarios, which together then enabled the identification of the adaptive pathways most likely to lead to the third horizon future pattern (Fig. 5). As with all approaches for working with complexity, good facilitation is also required. While in our experience the framework can be easily understood and facilitators can quickly learn how to apply the approach, the expertise of the facilitator has a significant bearing on the depth of insights achieved. We are therefore currently both exploring and experimenting with how Three Horizons can be used as a supportive and integrative framework with other methods while simultaneously developing appropriate online training for its facilitation and practice (http:// h3uni.net/). 
Table 3. Key propositions about deliberate transformation derived from observations and experience of facilitating the practice of Three Horizons (based on some of the insights in Sharpe 2013).

\begin{tabular}{|c|c|}
\hline Proposition & Explanation \\
\hline $\begin{array}{l}\text { Transformation requires development } \\
\text { of future consciousness. }\end{array}$ & $\begin{array}{l}\text { Future consciousness can be considered to be an awareness of the future potential of the present moment. It is } \\
\text { limited by a range of cognitive, psychological, and systemic issues, such as existing psychological investment in } \\
\text { the security of the status quo, fear of a new changed paradigm, which can trigger denial of the problems in the } \\
\text { present, and linear causal mindsets that limit appreciation of underlying systemic issues. Nevertheless, working } \\
\text { with Three Horizons suggests that everyone has a natural capacity to relate to the future and act in the present } \\
\text { moment to create that future, and this awareness can be deepened through reflective practice using approaches } \\
\text { such as Three Horizons. }\end{array}$ \\
\hline
\end{tabular}

Transformation involves a repatterning of collective lives rather than expansion of the current pattern.

Transformation needs to bring together personal aspects and wider structural aspects of change.

Simple structures are needed for integrative and transformative dialogue

Transformation can occur only as a universal shared practice in which every person is viewed as a unique source of insight and human potential.
Incremental changes can lead to transformation, but these changes act mostly to retain existing ways of doing things. This implies that it is important to work collectively to change existing patterns when transformation is needed and to identify what needs to be done in the present moment to work with the future in the long term.

Transformative innovation involves working with different qualities of the future in the present (in this case, the different horizons) in a way that brings together the inward looking aspect of reflecting on an individual or groups' future consciousness (the first proposition) and the outward looking aspect of collectively understanding patterns of change and response (the second proposition). That is, transformation needs to bring together the personal aspects (e.g., values, future consciousness) and those aspects that need to be changed. This is similar to ideas that highlight the importance of working across the personal, political, and practical spheres of society (Sharma 2007), and which affirm that the incorporation of ethics and aesthetics, in addition to seeking new knowledge, is essential for transformation to occur (Hanlon et al. 2012).

Simple and easily accessible approaches are needed to help work with diverse perspectives and provide opportunities for collective thinking about the future without being trapped by personal values, fears, or other emotional ties. Working with Three Horizons suggests that there is a need for such approaches to provide a balance between having some structure and avoiding inappropriate constraints on understanding. Approaches also need to help avoid getting stuck in discussions about different interpretations of concepts like transformation.

Human lives are a process of constant discovery and invention, with each person living a unique human life (Horton 2002). Building a fully shared capacity for future consciousness is essential for engendering hopes for transformation and moving toward a more just and equitable world.
Fig. 5. An example of the way Three Horizons $(3 \mathrm{H})$ can frame the use of other tools. It depicts the flow of a recent project led by one of the authors that explored how carbon pricing could be used to help drive the transformation of the world economy to a low carbon future. From the initial $3 \mathrm{H}$ exploration, the critical unknowns of approach were explored with both dilemmas and scenarios, which led to an understanding of the adaptive pathways to the third horizon.

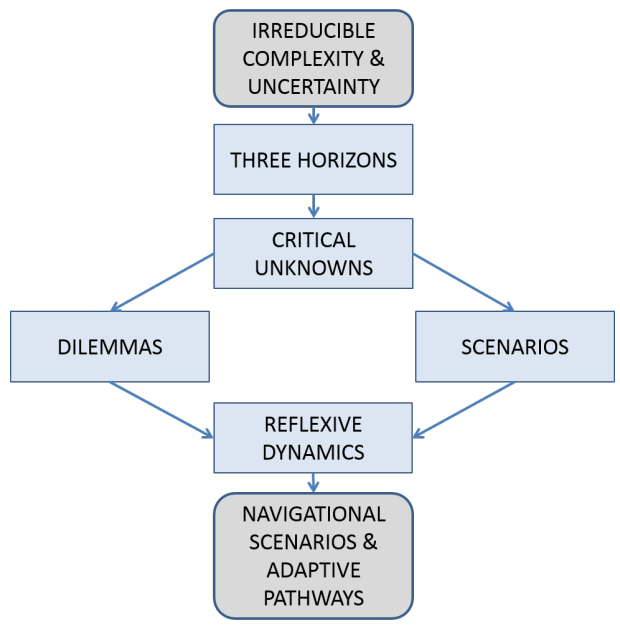

In addition to articulating what we think we know about the practice of Three Horizons, reflecting on its practice has helped identify insights about the nature of transformation itself (Table 3 ). We do not claim that these represent reproducible findings, but rather that they serve to represent the articulation of practical knowledge in epistemic ways. Such reflections through practice have, for example, helped us develop our own thinking about the differences between incremental and transformative change and how conversations about transformation can be facilitated. This highlights that new and important knowledge about the nature of change itself emerges from trying to do change as well as from analytical-deductive approaches that primarily seek to observe it. This is consistent with calls for researchers to engage more directly in processes of change to help accelerate learning for deliberate transformation (O'Brien 2012, Arkesteijn et al. 2015).

To accelerate learning about practices of change and transformation, we need participatory, reflective, and actionbased forms of research that simultaneously work with techne, phronesis, and episteme (Frame and Brown 2008, Reason and Bradbury 2008, Ison et al. 2014). These needs are reflected in wider calls for more open knowledge systems that are more inclusive, transparent, and action-oriented (Flyvberg 2001, Cornell et al. 2013, van Kerkhoff 2014, Kläy et al. 2015). Yet, despite the importance of the transformation agenda, currently there are limited avenues for funding research that works more 
directly with practical forms of knowledge (Kläy et al. 2015). This may seem surprising given the increasing emphasis on the need for research to be useful. Yet, usefulness is usually defined by existing policy and research environments that focus on research to address first horizon issues (i.e., "keeping the lights on") rather than on the processes and practices of third horizon renewal (Pardoe 2014). The challenge here is that for research to be effective in assisting transformation, a transformation in the way research is conducted and the acceptance of other forms of knowledge will also be required. Details of a new research agenda are beyond the scope of this paper, but such changes rest on greater acknowledgement by researchers and practitioners that all research is socially constructed and that observers are not independent from what is observed (Aufenvenne et al. 2014, Kläy et al. 2015). Moving toward new ways of thinking about research and knowledge production will require second horizon strategic actions that can assist the transition from the first horizon to new third horizon modes of research. Three Horizons would be useful for helping to begin to explore how such transitions might come about.

Responses to this article can be read online at: http://www.ecologyandsociety.org/issues/responses. php/8388

\section{Acknowledgments:}

We would like to thank the insightful comments provided by three anonymous reviewers. Jim Ewing first formulated the idea of the different voices in which each horizon typically speaks, and Ian Page developed those ideas into the horizon outlooks shown in Table 2. We are grateful to the many people who collaborated with us in exploring the possibilities of using Three Horizons for their projects, in particular those whose applications we report in Table 3. This work was partly supported by the Knowledge Network for Enabling Transformation project funded by the International Social Science Council (ISSC) (T2S_PP-067).

\section{LITERATURE CITED}

Ackoff, R. 1979. The art of problem-solving. John Wiley, New York, USA.

Aristotle. 2004. The Nicomachean ethics (translated by J. A. K. Thomson). Penguin Books, London, UK.

Arkesteijn, M., B. van Mierlo, and C. Leeuwis. 2015. The need for reflexive evaluation approaches in development cooperation. Evaluation 21:99-115. http://dx.doi.org/10.1177/1356389014564719

Aufenvenne, P., H. Egner, and K. Von Elverfeldt. 2014. On climate change research, the crisis of science and second-order science. Constructivist Foundations 10:120-129.

Barab, S. A., and J. A. Plucker. 2002. Smart people or smart contexts? Cognition, ability, and talent development in an age of situated approaches to knowing and learning. Educational Psychologist 37:165-182. http://dx.doi.org/10.1207/s15326985ep3703 3

Bell, W. 2003. Foundations of futures studies: history, purposes, and knowledge: 1 (Human science for a new era). Transaction Publishers, Piscataway, New Jersey.
Bergek, A., S. Jacobsson, B. Carlsson, S. Lindmark, and A. Rickne. 2008. Analyzing the functional dynamics of technological innovation systems: a scheme of analysis. Research Policy 37:407-429. http://dx.doi.org/10.1016/j.respol.2007.12.003

Borup, M., N. Brown, K. Konrad, and H. Van Lente. 2006. The sociology of expectations in science and technology. Technology Analysis and Strategic Management 18:285-298. http://dx.doi. org/10.1080/09537320600777002

Burns, D. 2007. Systemic action research: a strategy for whole system change. Policy Press, Bristol, UK.

Burns, D., and S. Worsley. 2015. Navigating complexity in international development: facilitating sustainable change at scale. Practical Action Publishing, Rugby, UK. http://dx.doi. org/10.3362/9781780448510

Câmpeanu, C. N., and I. Fazey. 2014. Adaptation and pathways of change and response: a case study from Eastern Europe. Global Environmental Change: Human and Policy Dimensions 28:351367. http://dx.doi.org/10.1016/j.gloenvcha.2014.04.010

Chandler, D. 2013. Resilience ethics: responsibility and the globally embedded subject. Ethics and Global Politics 6:175-194. http://dx.doi.org/10.3402/egp.v6i3.21695

Christie, M., I. Fazey, R. Cooper, T. Hyde, and J. O. Kenter. 2012. An evaluation of monetary and non-monetary techniques for assessing the importance of biodiversity and ecosystem services to people in countries with developing economies. Ecological Economics 83:67-78. http://dx.doi.org/10.1016/j.ecolecon.2012.08.012

Cornell, S., F. Berkhout, W. Tuinstra, J. D. Tàbara, J. Jäger, I. Chabay, B. de Wit, R. Langlais, D. Mills, P. Moll, I. M. Otto, A. Petersen, C. Pohl, and L. van Kerkhoff. 2013. Opening up knowledge systems for better responses to global environmental change. Environmental Science and Policy 28:60-70. http://dx.doi. org/10.1016/j.envsci.2012.11.008

Curry, A., and A. Hodgson. 2008. Seeing in multiple horizons: connecting futures to strategy. Journal of Futures Studies 13:1-20.

Fazey, I., N. Pettorelli, J. Kenter, D. Wagatora, and D. Schuett. 2011. Maladaptive trajectories of change in Makira, Solomon Islands. Global Environmental Change 21:1275-1289. http://dx. doi.org/10.1016/j.gloenvcha.2011.07.006

Fazey, I., R. M. Wise, C. Lyon, C. Câmpeanu, P. Moug, and T. E. Davies. 2015. Past and future adaptation pathways. Climate and Development 8:26-44. http://dx.doi.org/10.1080/17565529.2$\underline{014.989192}$

Flyvberg, B. 2001. Making social science matter: why social inquiry fails and how it can succeed again. Cambridge University Press. http://dx.doi.org/10.1017/CBO9780511810503

Folke, C. 2006. Resilience: the emergence of a perspective for social-ecological systems analyses. Global Environmental ChangeHuman and Policy Dimensions 16:253-267. http://dx.doi. org/10.1016/j.gloenvcha.2006.04.002

Folke, C., S. R. Carpenter, B. Walker, M. Scheffer, T. Chapin, and J. Rockström. 2010. Resilience thinking: integrating resilience, adaptability and transformability. Ecology and Society 15(4):2. http://www.ecologyandsociety.org/vol15/iss4/art20/ 
Frame, B., and J. Brown. 2008. Developing post-normal technologies for sustainability. Ecological Economics 65:225-241. http://dx.doi.org/10.1016/j.ecolecon.2007.11.010

Gallopin, G. C. 2006. Linkages between vulnerability, resilience, and adaptive capacity. Global Environmental Change-Human and Policy Dimensions 16:293-303. http://dx.doi.org/10.1016/j. gloenvcha.2006.02.004

Geels, F. W. 2014. Regime resistance against low-carbon transitions: introducing politics and power into the multi-level perspective. Theory, Culture and Society 31:21-40. http://dx.doi. org/10.1177/0263276414531627

Geels, F. W., and J. Schot. 2007. Typology of sociotechnical transition pathways. Research Policy 36:399-417. http://dx.doi. org/10.1016/j.respol.2007.01.003

Gerschel-Clarke, A. 2013. Are patent trolls strangling sustainable innovation? The Guardian.

Haasnoot, M., H. Middelkoop, A. Offermans, E. van Beek, and W. P. A. van Deursen. 2012. Exploring pathways for sustainable water management in river deltas in a changing environment. Climatic Change 115:795-819. http://dx.doi.org/10.1007/ $\underline{\text { s10584-012-0444-2 }}$

Hampden-Turner, C. 1990. Charting the corporate mind: graphic solutions to business conflicts. The Free Press, New York, USA.

Hanlon, P., S. Carlisle, M. Hannah, A. Lyon, and D. Reilly. 2012. A perspective on the future public health: an integrative and ecological framework. Perspectives in Public Health 132:313-319.

Hatt, K. 2013. Social attractors: a proposal to enhance 'resilience thinking' about the social. Society \& Natural Resources 26:30-43. http://dx.doi.org/10.1080/08941920.2012.695859

Hodgson, A. 2012. A transdisciplinary world model. Systems Research and Behavioral Science 29:517-526. http://dx.doi. org/10.1002/sres.2154

Höijer, B., R. Lidskog, and Y. Uggla. 2006. Facing dilemmas: sense-making and decision-making in late modernity. Futures 38:350-366. http://dx.doi.org/10.1016/j.futures.2005.07.007

Holling, C. S. 2001. Understanding the complexity of economic, ecological, and social systems. Ecosystems 4:390-405. http://dx. doi.org/10.1007/s10021-001-0101-5

Holling, C. S., and G. K. Meffe. 1996. Command and control and the pathology of natural resource management. Conservation Biology 10:328-337. http://dx.doi.org/10.1046/j.1523-1739.1996.10020328. $\underline{\mathrm{X}}$

Holman, P. 2011. Engaging emergence: turning upheaval into opportunity. Eighth International Conference on Complex Systems, New England Complex Systems Institute, Massachusetts, USA.

Horton, S. L. 2002. Conceptualizing transition: the role of metaphor in describing the experience of change at midlife. Journal of Adult Development 9:277-290.

Intergovernmental Panel on Climate Change (IPCC). 2013. Climate change 2013: the physical science basis. IPCC Working Group I Contribution to AR5. Intergovernmental Panel on Climate Change, Stockholm, Sweden.
International Social Science Council (ISSC). 2012. Transformative cornerstones of social science research for global change. International Social Science Council, Paris, France.

International Social Science Council (ISSC) and United Nations Educational, Scientific and Cultural Organization (UNESCO). 2013. World social science report: changing global environments, Paris, France.

Ison, R., A. Grant, and R. Bawden. 2014. Scenario praxis for systemic governance: a critical framework. Environment and Planning C: Government and Policy 32:623-640. http://dx.doi. org/10.1068/c11327

Kahane, A. 2012. Transformative scenario planning: working together to change the future. Berrett-Koehler Publishers, San Francisco, California, USA.

Kenter, J. O., L. O'Brien, N. Hockley, N. Ravenscroft, I. Fazey, K. N. Irvine, M. S. Reed, M. Christie, E. Brady, R. Bryce, A. Church, N. Cooper, A. Davies, A. Evely, M. Everard, R. Fish, J. A. Fisher, N. Jobstvogt, C. Molloy, J. Orchard-Webb, S. Ranger, M. Ryan, V. Watson, and S. Williams. 2015. What are shared and social values of ecosystems? Ecological Economics 111:86-99. http://dx.doi.org/10.1016/j.ecolecon.2015.01.006

Kläy, A., A. B. Zimmermann, and F. Schneider. 2015. Rethinking science for sustainable development: reflexive interaction for a paradigm transformation. Futures 65:72-85. http://dx.doi. org/10.1016/j.futures.2014.10.012

Kok, K., M. van Vliet Mathijs, I. Bärlund Ilona, A. Dubel, and J. Sendzimir. 2011. Combining participative backcasting and exploratory scenario development: experiences from the SCENES project. Technological Forecasting and Social Change 78:835-851. http://dx.doi.org/10.1016/j.techfore.2011.01.004

Leach, M. 2008. Pathways to sustainability in the forest? Misunderstood dynamics and the negotiation of knowledge, power, and policy. Environment and Planning A 40:1783-1795. http://dx.doi.org/10.1068/a40215

Leicester, G., and M. O'Hara. 2009. Ten things to do in a conceptual emergency. International Futures Forum, Aberdour, Scotland.

Leicester, G., D. Stewart, K. Bloomer, and J. Ewing. 2013. Transformative innovation in education: a playbook for pragmatic visionaries. Triarchy Press, Axminster, UK.

Ma, D. 2013. State capacity and great divergence, the case of Qing China (1644-1911). Eurasian Geography and Economics 54:484 499.

Mahony, T. O. 2014. Integrated scenarios for energy: a methodology for the short term. Futures 55:41-57. http://dx.doi. org/10.1016/j.futures.2013.11.002

McGowan, K. A., F. Westley, E. D. G. Fraser, P. A. Loring, K. C. Weathers, F. Avelino, J. Sendzimir, R. R. Chowdhury, and M. L. Moore. 2014. The research journey: travels across the idiomatic and axiomatic toward a better understanding of complexity. Ecology and Society 19. http://dx.doi.org/10.5751/es-06518-190337

Miller, R. 2011. Futures literacy: embracing complexity and using the future. Ethos 10:23-28. 
Milojević, I., and A. Izgarjan. 2014. Creating alternative futures through storytelling: a case study from Serbia. Futures 57:51-61. http://dx.doi.org/10.1016/j.futures.2013.12.001

Moore, G. E. 1965. Cramming more components onto integrated circuits. Electronics 38. http://dx.doi.org/10.1109/jproc.1998.658762

Newell, B. 2012. Simple models, powerful ideas: towards effective integrative practice. Global Environmental Change 22:776-783. http://dx.doi.org/10.1016/j.gloenvcha.2012.03.006

Nicholls, R. J., N. Marinova, J. A. Lowe, S. Brown, P. Vellinga, D. De Gusmão, J. Hinkel, and R. S. J. Tol. 2011. Sea-level rise and its possible impacts given a 'beyond $4^{\circ} \mathrm{C}$ world' in the twenty-first century. Philosophical Transactions of the Royal Society A: Mathematical, Physical and Engineering Sciences 369:161-181. http://dx.doi.org/10.1098/rsta.2010.0291

O'Brien, K. 2011. Responding to environmental change: a new age for human geography? Progress in Human Geography 35:542549. http://dx.doi.org/10.1177/0309132510377573

O'Brien, K. 2012. Global environmental change II: from adaptation to deliberate transformation. Progress in Human Geography 36:667-676. http://dx.doi.org/10.1177/0309132511425767

O'Brien, K. 2013. Global environmental change III: closing the gap between knowledge and action. Progress in Human Geography 37:587-596. http://dx.doi.org/10.1177/0309132512469589

O'Brien, K., J. Reams, A. Caspari, A. Dugmore, M. Faghihimani, I. Fazey, H. Hackmann, D. Manuel-Navarrete, J. Marks, R. Miller, K. Raivio, P. Romero-Lankao, H. Virji, C. Vogel, and V. Winiwarter. 2013. You say you want a revolution? Transforming education and capacity building in response to global change. Environmental Science and Policy 28:48-59. http://dx.doi. org/10.1016/j.envsci.2012.11.011

O'Brien, K., and L. Sygna. 2013. Responding to climate change: the three spheres of transformation. In K. O'Brien, and L. Sygna, editors. Proceedings of Transformation in a Changing Climate. June 19-21 2013. University of Oslo, Oslo, Norway.

Ogilvy, J. A. 2002. Creating better futures. Oxford University Press, New York, USA.

Pardoe, S. 2014. Research impact unpacked? A social science agenda for critically analyzing the discourse of impact and informing practice. SAGE Open 4 . http://dx.doi. org/10.1177/2158244014529774

Pelling, M. 2011. Adaptation to climate change: from resilience to transformation. Routledge, London, UK.

Perez, C. 2004. Finance and technical change: a long-term view. Pages 775-799 in H. Hanusch, and A. Pyka, editors. The Elgar companion to neo-Schumpeterian economics. Edward Elgar, Cheltenham, UK. http://dx.doi.org/10.4337/9781847207012.00059

Peterson, G. D., G. S. Cumming, and S. R. Carpenter. 2003. Scenario planning: a tool for conservation in an uncertain world. Conservation Biology 17:358-366. http://dx.doi.org/10.1046/ j.1523-1739.2003.01491.X

Proust, K., B. Newell, H. Brown, A. Capon, C. Browne, A. Burton, J. Dixon, L. Mu, and M. Zarafu. 2012. Human health and climate change: leverage points for adaptation in urban environments. International Journal of Environmental Research and Public Health 9:2134-2158. http://dx.doi.org/10.3390/ ijerph9062134

Pryjmachuk, S. 1996. A nursing perspective on the interrelationships between theory, research and practice. Journal of Advanced Nursing 23:679-684. http://dx.doi.org/10.1111/ j.1365-2648.1996.tb00037.x

Ramirez, R., J. W. Selsky, and K. van der Heijden. 2008. Business planning for turbulent times: new methods for applying scenarios. Earthscan, London, UK.

Ramirez, R., and K. Van der Heijden. 2007. Scenarios to develop strategic options: a new interactive role for scenarios in strategy. In B. Sharpe, and K. Van der Heijden, editors. Scenarios for success: turning insights in to action. Wiley, Chichester, UK. http:// dx.doi.org/10.1002/9781119208136.ch4

Reason, P., and H. Bradbury. 2008. The Sage handbook of action research: participative inquiry and practice. Sage, London, UK. http://dx.doi.org/10.4135/9781848607934

Rittel, H. W. J., and M. M. Webber. 1973. Dilemmas in a general theory of planning. Policy Sciences 4:155-169. http://dx.doi. org/10.1007/bf01405730

Rockstrom, J., W. Steffen, K. Noone, A. Persson, F. S. Chapin, E. Lambin, T. M. Lenton, M. Scheffer, C. Folke, H. J. Schellnhuber, B. Nykvist, C. A. de Wit, T. Hughes, S. van der Leeuw, H. Rodhe, S. Sorlin, P. K. Snyder, R. Costanza, U. Svedin, M. Falkenmark, L. Karlberg, R. W. Corell, V. J. Fabry, J. Hansen, B. Walker, D. Liverman, K. Richardson, P. Crutzen, and J. Foley. 2009. Planetary boundaries: exploring the safe operating space for humanity. Ecology and Society 14(2):32. http://www. ecologyandsociety.org/vol14/iss2/art32/

Rolfe, G. 1998. The theory-practice gap in nursing: from researchbased practice to practitioner-based research. Journal of Advanced Nursing 28:672-679. http://dx.doi.org/10.1046/ j.1365-2648.1998.00806.x

Rosenhead, J. 2006. Past, present and future of problem structuring methods. Journal of the Operational Research Society 57:759-765. http://dx.doi.org/10.1057/palgrave.jors.2602206

Sardar, Z. 2010. Welcome to postnormal times. Futures 42:435444. http://dx.doi.org/10.1016/j.futures.2009.11.028

Saritas, O., and J. Aylen. 2010. Using scenarios for roadmapping: the case of clean production. Technological Forecasting and Social Change 77:1061-1075. http://dx.doi.org/10.1016/j.techfore.2010.03.003

Schleicher-Tappeser, R. 2012. How renewables will change electricity markets in the next five years. Energy Policy 48:64-75. http://dx.doi.org/10.1016/j.enpol.2012.04.042

Sharma, M. 2007. Personal to planetary transformation. Kosmos Journal Fall/Winter:31-35.

Sharpe, B. 2013. Three horizons: patterning of hope. Triarchy Press, Axminster, Devon, UK.

Sharpe, B., and A. Hodgson. 2006. Intelligent infrastructure futures: technology forward look. Foresight Directorate, UK Dept of Trade \& Industry, London, UK. 
Shotter, J., and H. Tsoukas. 2014. In search of phronesis: leadership and the art of judgment. Academy of Management Learning and Education 13:224-243. http://dx.doi.org/10.5465/ amle.2013.0201

Stafford-Smith, M., L. Horrocks, A. Harvey, and C. Hamilton. 2011. Rethinking adaptation for a 4C world. Philosophical Transactions of the Royal Society A 369:196-216.

Stanford, M. 2012. Eco thugs: how patent trolls threaten to undermine a sustainable energy future. Green Living Press. http:// blog.loomistank.com/2012/02/23/eco-thugs-how-patent-trolls-threatento-undermine-a-sustainable-energy-future/

Tibbs, H. 2011. Changing cultural values and the transition to sustainability. Journal of Futures Studies 15:13-32.

Valorinta, M., H. Schildt, and J. A. Lamberg. 2011. Path dependence of power relations, path-breaking change and technological adaptation. Industry and Innovation 18:765-790. http://dx.doi.org/10.1080/13662716.2011.621745

Van De Ven, A. H., and P. E. Johnson. 2006. Knowledge for theory and practice. Academy of Management Review 31:802-821. http:// dx.doi.org/10.5465/amr.2006.22527385

Van der Heijden, K. 2005. Scenarios: the art of strategic conversation. John Wiley \& Sons, Chichester, UK.

van Kerkhoff, L. 2014. Developing integrative research for sustainability science through a complexity principles-based approach. Sustainability Science 9:143-155. http://dx.doi. org/10.1007/s11625-013-0203-y

van Notten, P. W. F., J. Rotmans, M. B. A. van Asselt, and D. S. Rothman. 2003. An updated scenario typology. Futures 35:423443. http://dx.doi.org/10.1016/s0016-3287(02)00090-3

Videira, N., F. Schneider, F. Sekulova, and G. Kallis. 2014. Improving understanding on degrowth pathways: an exploratory study using collaborative causal models. Futures 55:58-77. http:// dx.doi.org/10.1016/j.futures.2013.11.001

Voß, J. P., J. Newig, B. Kastens, J. Monstadt, and B. Nölting. 2007. Steering for sustainable development: a typology of problems and strategies with respect to ambivalence, uncertainty and distributed power. Journal of Environmental Policy and Planning 9:193-212. http://dx.doi.org/10.1080/15239080701622881

Waddock, S., G. M. Meszoely, S. Waddell, and D. Dentoni. 2015. The complexity of wicked problems in large scale change. Journal of Organizational Change Management 28:993-1012. http://dx. doi.org/10.1108/jocm-08-2014-0146

Walker, B., C. S. Hollin, S. R. Carpenter, and A. Kinzig. 2004. Resilience, adaptability and transformability in social-ecological systems. Ecology and Society 9(2):5. http://www.ecologyandsociety. org/vol9/iss2/art5/

Weisbord, W., and S. Jasanoff. 2010. Future search: getting the whole system in the room for vision, commitment, and action. Third edition. Berrett-Koehler, San Francisco, California, USA.

Whiteman, G., B. C. Forbes, J. Niemela, and F. S. Chapin. 2004. Bringing feedback and resilience of high-latitude ecosystems into the corporate boardroom. Ambio 33:371-376. http://dx.doi. org/10.1579/0044-7447-33.6.371
Wicks, A., and M. Jamieson. 2014. New ways for occupational scientists to tackle "wicked problems" impacting population health. Journal of Occupational Science 21:81-85. http://dx.doi. org/10.1080/14427591.2014.878208

Wise, R. M., J. R. A. Butler, T. Skewes, E. Bohensky, and N. Peterson. 2014a. The future economics of marine ecosystem services in Kimbe Bay, Papua New Guinea: implications for locally managed marine areas. Report prepared for the Australian Department of Environment as part of the Coral Triangle Initiative on Coral Reefs, Food Security and Fisheries. CSIRO, Canberra, Australia.

Wise, R. M., I. Fazey, M. Stafford Smith, S. E. Park, H. C. Eakin, E. R. M. Archer Van Garderen, and B. Campbell. $2014 b$. Reconceptualising adaptation to climate change as part of pathways of change and response. Global Environmental Change 28:325-336. http://dx.doi.org/10.1016/j.gloenvcha.2013.12.002 